\title{
Testing the Relationship between Government Expenditure and Private Investment: The Case of Small Open Economies
}

\author{
Lina Sinevičienè
}

\begin{abstract}
This paper examines relationship between government expenditure and private investment in the case of small open economies. Governments could promote private investment increasing government expenditure, but increase of government expenditure can both crowd out and crowd in private investment. In order to assess relationship between government expenditure and private investment in this research, cross-correlations and Granger causality tests are applied using data of Bulgaria, Estonia, Latvia, Lithuania and Slovenia during 1996 - 2012. The research results show that impact of government expenditure increase on private investment is very weak, but negative impact of government expenditure increase on private investment dominates, except in the case of Bulgaria; whereas the impact of private investment increase on government expenditure is very different in analyzed countries.
\end{abstract}

Index Terms-Fiscal policy, government expenditure, private investment, small open economy.

\section{INTRODUCTION}

Government's fiscal policy is one of the tools used for economic stabilization purposes. However, the last financial crisis has shown that fiscal policy was not effective, as was expected. Decrease in governments' revenue has led to the rapid growth of countries' public debt. Economic stabilization measures have not been effective and economic stabilization objectives have not been achieved. Public finance problems, demographic and social changes in recent years promote scientists and politicians' debate on the changing role of the state and decreasing government's spending impact on the real economy. Government's expenditure policy impact on private investment is a particularly relevant issue, because private investment is one of the main growth drivers in the long-run.

Theoretically, Rahn curve can explain the decreased impact of government's expenditure on the economy and private investment, because governments' expenditure levels have reached the point where government's expenditure growth should slow down the economic growth [1]. According to neoclassical growth theory, it is stated that increasing public spending, especially if it is financed by debt, causes private investment crowding out effect. The impact of public expenditure on private investment was analyzed by [2]-[5] and others. According to various scientific studies,

Manuscript received November 25, 2013; revised January 17, 2014.

Lina Sinevičiene is with the Faculty of Economics and Management, Kaunas University of Technology, K. Donelaičio str. 73, LT-44029, Kaunas, Lithuania (e-mail: lina.sineviciene@ktu.lt). unambiguous conclusions cannot be provided on the impact of government's expenditure on private investment because government expenditure can crowd in or crowd out private investment in developed and developing countries. However, scientific studies emphasize negative impact of government budget deficit and increasing debt on private investment due to increasing interest rates to the private sector and the probability that tax rates will be increased in the future. The debatable aspects of government's fiscal policy effectiveness in the scientific literature in recent years have shown that it is important to determine the impact of government expenditure on private investment. This research is especially relevant in the context of limited public finances in the case of small open economies. In the scientific literature, the prevailing view is that fiscal policy is less effective in small open economies than in large economies, therefore it is important to assess whether the government can contribute to the growth of private investment, increasing public spending. The results of empirical studies have shown that, when the relationship between government expenditure and private investment is assessed, there are no estimated cyclical changes of government expenditure and private investment, resulting in inaccurate results. Thus the novelty of this research is described by the assessment of fiscal policy relationship with private investment in small open economies, evaluating the cyclical components of government expenditure and private investment. The aim of the research: to identify the relationship between government expenditure and private investment in small open economies. The research object: relationship between government expenditure and private investment. The research methods: analysis and synthesis of scientific literature, logic analysis and synthesis, analysis of statistical data, econometrical statistical methods.

\section{PeCUliarities of Fiscal Policy EFFeCtiveness IN SMALL OPEN ECONOMIES}

Small economies differ from large economies by economical, social and political factors. In the current circumstances it is difficult to identify closed economies; almost all economies are open, and they only differ in a degree of openness. The size and openness of the economy determine special positive and negative characteristics of the economy. The impact of government's expenditure on private investment may differ according to the economy size and openness too. This paper examines the impact of government expenditure on private investment in the case of small open economies. 
Small open economies tend to have higher growth volatility, as small open economies are more vulnerable to external economic shocks. This feature of small open economies is confirmed by a compensation hypothesis. According to [6], governments have to increase their expenditures in order to smooth out this volatility and mitigate the risks. But according to efficiency hypothesis, trade openness reduces the total revenue of the government with cut in tariff rate and taxes which reduce the government ability to smooth out volatility [6], [7] noted that higher growth volatility is the consequence of pursuing procyclical fiscal policies in small open economies.

In large open economies, economic policy decisions generate externalities to the other countries; the effects of the interaction among the economies are greater, if the degree of openness and economic integration is greater [8]. Therefore, not only economic openness will cause a country to be more vulnerable when facing external shocks, but also its inability to compete with other countries [8], [9] noted that the higher openness may entail risk diversification, it may promote rather than reduce stability, but smaller economies should experience greater levels of volatility than larger economies.

Empirical findings of [10] showed that the effectiveness of fiscal policy is indeed reduced by the economy's trade openness, and that the effect is quantitatively substantial (annual data from the period 1951-2007, for 62 developed and developing economies). [11] provided supporting evidence, using panel data for 19 OECD countries, that crowding out effects on consumption and investment are found to be decreasing in a country's openness to trade. Empirical results of [12] showed that fiscal multipliers in open economies are smaller than in closed economies, as fiscal multipliers in high-debt countries are negative.

The conducted theoretical research showed that governments of small open economies confront with larger limitations pursuing fiscal policy, because fiscal policy measures are less effective in small open economies.

\section{CROWDING IN AND CROWDING OUT EFFECTS OF GOVERNMENT's EXPENDITURE ON PRIVATE INVESTMENT}

In the scientific literature, there are various theoretical approaches considering crowding in and crowding out effects of government's expenditure on private investment. Various authors' empirical are differing very much.

Ref. [13] provided important insights on the potential private investment's crowding out possibilities. The author argues that in the developed countries increased government spending crowds out private investment, whereas in the developing countries government expenditure crowds in private investment. [13] argued that in the developed countries, the available resources are fully utilized, therefore increase in public spending leads to the constraints of private sector's financial resource to fund the activities. Private investment decisions are mainly dependent on the economic conditions in developing countries; and government spending provides necessary incentives to attract private funds.

Ref. [14] concluded that government expenditure crowds in private investment, but emphasized the strong negative effect of real interest rate on private investment. Crowding in effect of private investment was found by [15], however, it was noted that budget deficit crowds out private investment. [5] makes similar conclusions, but it was noted that, when assessing the impact of government expenditure on private investment, it is necessary to take into account whether the growth of government expenditure does not increase the budget deficit and thus do not reduce the positive impact of government expenditure increase on private investment.

Ref. [20] noted that the decline of government expenditure to GDP ratio could result in growth of capital investment and, at the same time, economic growth in the long-run. This view is supported by [3], [4]. According to [3], [4], government expenditure creates a significant crowding out effect, which has a negative impact on both private consumption and investment. In addition, [3], [4] argued that government expenditure's impact is not significantly different according to the different stages of the economic cycle, but it is very different between the regions. As indicated by [3], impact of government expenditure on private investment is important and should be examined considering different geographic regions. It was indicated by [4] that the impact of government expenditure on private investment varies between OECD and non-member countries of this organization (stronger crowding out effect is in OECD countries), but does not depend on the stage of the business cycle. However, expansionary fiscal policy leads to greater crowding out effect than contractionary fiscal policy.

Nevertheless different empirical findings of various authors, the prevailing view is that government expenditure crowds in private investment in developing countries and crowds out private investment in developing countries. Despite these results, it is not clear what impact of government expenditure on private investment is in small open economies.

\section{Methodology}

In order to determine the relationship between government expenditure and private investment, first of all, cyclical government expenditure and private investment's components are determined using a Hodrick - Prescott filter. For this purpose, government expenditure and private investment time series are used. Government expenditure and private investment indicators are measured as real annual change (in percent). As a result, government expenditure and private investment's two time series components are isolated using Hodrick - Prescott filter - a stochastic trend and cyclical component, for each country separately.

Hodrick - Prescott filter aims at removing a smooth trend $\tau_{t}$ from some given data $y_{t}$ by solving minimization problem [16]-[18]:

$$
\min _{\tau_{t}} \sum_{t=1}^{\tau}\left(\left(y_{t}-\tau_{t}\right)^{2}+\lambda\left(\left(\tau_{t+1}-\tau_{t}\right)-\left(\tau_{t}-\tau_{t-1}\right)\right)^{2}\right.
$$

where $\lambda-$ the penalty parameter is set to 6.25 (according to the recommendations of [17]).

Then, the cyclical component $c_{t}$ can be identified as follows [16], [17]: 


$$
c_{t}=y_{t}-\tau_{t}
$$

Government expenditure and private investment indicators are measured as real percentage annual change. Nominal indicators' values are converted into real values using the deflator of real total expenditure of general government and deflator of gross fixed capital formation respectively (where $100=2005$ year).

When the cyclical government expenditure and private investment's components are isolated, the relationship between cyclical government expenditure and private investment's cyclical components is assessed using cross-correlation and Granger causality test. Cross-correlation and Granger causality test are used to assess the relationship between real changes of government total expenditure and private investment too. Before applying cross-correlation and Granger causality test in time series, unit root tests of variables are carried out and it is being controlled whether time series are stationary or not. If time series are not stationary, they are differenced.

Data Empirical analysis focuses on the data of European Union members: Bulgaria, Estonia, Latvia, Lithuania and Slovenia. Various indicators are collected from Eurostat Statistics [19] (GDP, millions of EUR; GDP, EUR per inhabitant; Investment, EUR per inhabitant; Private investment, \% of GDP), Annual Macroeconomic Database of the European Commission [20] (General government total expenditure, gross fixed capital formation by private sector, Price deflator of gross fixed capital formation, Price deflator of real total expenditure of general government), World development indicators [21] (Trade, \% of GDP) databases. The study covers the period from 1996 till 2012, using annual data.

In this research, the openness of the economy is measured as trade percentage of GDP. Trade is the sum of exports and imports of goods and services measured as a share of GDP [21]. The size of the economy is measured as GDP (millions of EUR). The investment is measured as gross fixed capital formation indicator. Government expenditure is general government's total expenditure.

\section{EMPIRICAL RESULTS}

Table I shows that all selected countries for the study are small open economies. The size of economies is measured as GDP (millions of EUR); and it had not exceed more than 40000 millions of EUR in 2012. Latvian and Estonian economies are the smallest, but Estonian economic openness is the highest compared with four other selected countries. The economic development (measured as GDP per inhabitant) is the highest in Slovenia, while the lowest - in Bulgaria; and it is lower 2-3 times than in other selected countries. The highest level of investment was in Estonia, whereas the lowest - in Lithuania and Slovenia. The level of government investment was very low in Slovenia; and this explains why the level of overall investment was low in this country compared with Bulgaria, Estonia and Latvia in 2012. Slovenian government's sector was relatively large; general government sector total expenditure was equal to 48.1 percent of GDP, whereas the level of government's expenditure did not exceed 40 percent of GDP in other countries. The highest level of the government debt was in the case of Slovenia; and this can be associated with relatively large government's sector. The discussed indicators are important, because they may determine what effect of government expenditure on private investment could occur. According to scientific literature, higher government expenditure and debt levels may determine crowding out private investment effect. The levels of government expenditure and government debt were not high compared with other European Union countries in the case of analyzed countries. Only the indicators of Slovenia's government expenditure and government debt may signal about potential negative impact of increasing government expenditure on private investment.

TABLE I: COUNTRIES’ AGGREGATES IN 2012 YEAR

\begin{tabular}{|l|c|c|c|c|c|}
\hline \multicolumn{1}{|c|}{ Indicator } & Bulgaria & Estonia & Latvia & Lithuania & Slovenia \\
\hline Trade, \% of GDP & 137.0 & 184.4 & 125.7 & 167.9 & 147.3 \\
\hline GDP, millions of EUR & 39667.7 & 17415.1 & 22256.9 & 32939.8 & 35.318 .6 \\
\hline GDP, EUR per inhabitant & 5400 & 13000 & 10900 & 11000 & 17200 \\
\hline Investment, \% of GDP & 21.4 & 25.2 & 22.8 & 16.6 \\
\hline Private investment, \% of GDP & 18.7 & 19.6 & 18.1 & 12.6 & 17.8 \\
\hline General government expenditure, \% of GDP & 35.9 & 39.5 & 36.5 & 36.1 & 48.1 \\
\hline Government consolidated gross debt & 18.5 & 9.8 & 40.6 & 40.5 & 54.4 \\
\hline
\end{tabular}

In order to estimate relationship between government expenditure and private investment, the data was tested if it was stationary. Unit root tests were performed before evaluating cross-correlations. According to [22], cross-correlation procedure could be used only on series that are stationary.

Summary of Panel unit root tests' (Augmented Dickey-Fuller test) results is shown in Table II. In Table II there is shown in which degree of differences (marked with $\mathrm{X}$ ) variables of each country became stationary and passed unit root test. Time series of cyclical components were stationary without differencing them, except in the case of Latvia; whereas variables of real government expenditure and private investment annual change became stationary after differencing them.

The cross-correlations between government expenditure and private investment show (see Table III), that weak correlations between government expenditure and private 
investment existed in the case of analyzed countries. The relationship between government expenditure and private investment is different in analyzed countries, therefore it is not possible to determine general tendency. [23] assessed that fiscal policy was procyclical during 1995 - 2010 in these countries, this means that government expenditure's cyclical component increased when country's GDP cyclical component increased in zero lag. Results show that cyclical component of government expenditure moved to the same direction as private investment in the case of analyzed countries, except Bulgaria in zero lag. This means that government increased its expenditure when private investment was increasing.

TABLE II: UNIT ROOT TEST RESULTS

\begin{tabular}{l|c|c|c|c|c|c|c|c|c|c}
\hline \multirow{2}{*}{ Indicator } & \multicolumn{7}{|c|}{$\boldsymbol{y}_{t}(\mathbf{P I})$} & \multicolumn{7}{|c|}{$\boldsymbol{y}_{t}(\mathbf{G E})$} & \multicolumn{7}{c}{$\boldsymbol{c}_{\boldsymbol{t}}(\mathbf{P I})$} & \multicolumn{2}{c}{$\boldsymbol{c}_{\boldsymbol{t}}(\mathbf{G E})$} \\
\hline & \multicolumn{7}{|c}{ Degree of differencing } \\
\hline Country & $\mathbf{0}$ & $\mathbf{1}^{*}$ & $\mathbf{2}^{* *}$ & $\mathbf{0}$ & $\mathbf{1}^{*}$ & $\mathbf{2}^{* *}$ & $\mathbf{0}$ & $\mathbf{1}^{*}$ & $\mathbf{0}$ & $\mathbf{1}^{*}$ \\
\hline Bulgaria & & & $X$ & & & $X$ & $X$ & & $X$ & \\
\hline Estonia & & & $X$ & & & $X$ & $X$ & & $X$ & \\
\hline Latvia & & & $X$ & & & $X$ & & $X$ & & $X$ \\
\hline Lithuania & & $X$ & & & $X$ & & $X$ & & $X$ & \\
\hline Slovenia & & $X$ & & & $X$ & & $X$ & & $X$ & \\
\hline \hline
\end{tabular}

Notes: $X$ indicates when data is stacionary;

* - first differencing; $* *$ - second differencing.

$y_{t}(\mathrm{PI})$ - private investment, annual percentage change;

$y_{t}(\mathrm{GE})$ - government expenditure, annual percentage change;

$c_{t}(\mathrm{PI})$ - cyclical component of private investment;

$c_{t}(\mathrm{PI})$ - cyclical component of government expenditure.
Government expenditure's cyclical component increase led private investment to grow after one year in the case of Bulgaria. In the case of Estonia leading indicator was private investment; private investment led to grow government expenditure with time lag of one year. The same relationship, as in the case of Estonia, was established in Slovenia. In the case of Latvia, private investment led to grow government expenditure with time lag of two years. In the case of Estonia, there also is the evidence that increase of government expenditure's cyclical component led to decrease private investment's cyclical component after 3 years. This effect occurred also after two years when government expenditure increased, but was weaker. In the case of Lithuania, the increase of government expenditure led to the reduction of private investment after two years. The results of relationship between government expenditure and private investment were very similar using cyclical components of variables with results when changes of variables were used. Only in the case of Bulgaria, according to cross-correlation procedure results, the strongest correlations were not in the same lags, nevertheless the signs of correlations coincided in different lags. Also in the case of Estonia, there was very similar situation. The results have shown that negative impact of government expenditure increase on private investment dominated, whereas the effect of private investment increase on government expenditure was very different in analyzed countries.

TABLE III: CROSS-CORRELATIONS BETWEEN GOVERNMENT EXPENDITURE AND PRIVATE INVESTMENT

\begin{tabular}{|c|c|c|c|c|c|c|c|c|c|c|}
\hline \multirow[b]{2}{*}{ Lag } & \multicolumn{2}{|c|}{ Bulgaria } & \multicolumn{2}{|c|}{ Estonia } & \multicolumn{2}{|c|}{ Latvia } & \multicolumn{2}{|c|}{ Lithuania } & \multicolumn{2}{|c|}{ Slovenia } \\
\hline & $\begin{array}{l}y_{t}(\mathrm{GE}) \\
\text { with } y_{t}(\mathrm{PI})\end{array}$ & $\begin{array}{l}c_{t}(\mathrm{GE}) \\
\text { with } c_{t}(\mathrm{PI})\end{array}$ & $\begin{array}{l}y_{t}(\mathrm{GE}) \\
\text { with } y_{t}(\mathrm{PI})\end{array}$ & $\begin{array}{l}c_{t}(\mathrm{GE}) \\
\text { with } \mathrm{c}_{t}(\mathrm{PI})\end{array}$ & $\begin{array}{l}y_{t}(\mathrm{GE}) \\
\text { with } y_{t}(\mathrm{PI})\end{array}$ & $\begin{array}{l}c_{t}(\mathrm{GE}) \\
\text { with } \mathrm{c}_{t}(\mathrm{PI})\end{array}$ & $\begin{array}{l}y_{t}(\mathrm{GE}) \\
\text { with } y_{t}(\mathrm{PI})\end{array}$ & $\begin{array}{l}c_{t}(\mathrm{GE}) \\
\text { with } c_{t}(\mathrm{PI})\end{array}$ & $\begin{array}{l}y_{t}(\mathrm{GE}) \\
\text { with } y_{t}(\mathrm{PI})\end{array}$ & $\begin{array}{l}c_{t}(\mathrm{GE}) \\
\text { with } \mathrm{c}_{t}(\mathrm{PI})\end{array}$ \\
\hline-3 & 0.020 & 0.019 & -0.078 & -0.206 & -0.284 & -0.124 & 0.007 & 0.021 & -0.040 & -0.103 \\
\hline-2 & 0.124 & 0.053 & -0.261 & -0.090 & 0.484 & 0.421 & -0.078 & -0.108 & -0.136 & -0.096 \\
\hline-1 & -0.228 & -0.187 & 0.319 & 0.361 & -0.436 & -0.301 & -0.034 & -0.042 & 0.351 & 0.357 \\
\hline 0 & -0.254 & -0.181 & -0.082 & 0.170 & 0.250 & 0.231 & 0.206 & 0.257 & 0.106 & 0.174 \\
\hline 1 & 0.242 & 0.455 & 0.081 & -0.001 & 0.168 & 0.104 & 0.196 & 0.162 & -0.185 & -0.218 \\
\hline 2 & -0.086 & -0.006 & -0.152 & -0.274 & -0.374 & -0.420 & -0.324 & -0.331 & -0.110 & -0.244 \\
\hline 3 & 0.135 & -0.003 & -0.249 & -0.376 & -0.035 & -0.030 & -0.030 & -0.100 & -0.171 & -0.181 \\
\hline
\end{tabular}

Note: The strongest correlations are marked in gray

TABLE IV: PAIRWISE GRANGER CAUSALITY TESTS

\begin{tabular}{|c|c|c|c|c|}
\hline Null Hypothesis: & Lags & Obs & F-Stat & Prob. \\
\hline \multicolumn{5}{|l|}{ Estonia } \\
\hline$c_{t}(\mathrm{PI})$ does not Granger Cause $c_{t}(\mathrm{GE})$ & 1 & 16 & 317.438 & $0.0982 *$ \\
\hline$c_{t}(\mathrm{GE})$ does not Granger Cause $c_{t}(\mathrm{PI})$ & & & 0.00132 & 0.9716 \\
\hline $\mathrm{c}_{t}(\mathrm{PI})$ does not Granger Cause $c_{t}(\mathrm{GE})$ & 2 & 15 & 318.044 & $0.0853^{*}$ \\
\hline$c_{t}(\mathrm{GE})$ does not Granger Cause $c_{t}(\mathrm{PI})$ & & & 0.46559 & 0.6407 \\
\hline$y_{t}(\mathrm{GE})$ does not Granger Cause $y_{t}(\mathrm{PI})$ & 1 & 14 & $5.2 \mathrm{E}-05$ & 0.9944 \\
\hline$y_{t}(\mathrm{PI})$ does not Granger Cause $y_{t}(\mathrm{GE})$ & & & 464.232 & $0.0542 *$ \\
\hline$y_{t}(\mathrm{GE})$ does not Granger Cause $y_{t}(\mathrm{PI})$ & 2 & 13 & 609.306 & $0.0247^{* *}$ \\
\hline$y_{t}(\mathrm{PI})$ does not Granger Cause $y_{t}(\mathrm{GE})$ & & & 427.166 & $0.0547 *$ \\
\hline$y_{t}(\mathrm{GE})$ does not Granger Cause $y_{t}(\mathrm{PI})$ & 3 & 12 & 893.549 & $0.0188 * *$ \\
\hline
\end{tabular}

Notes: $(* *),(*)$ indicate probability to reject the null hypothesis with respectively 5,10 percent significance. 
Granger causality tests were performed to confirm results obtained by performing cross-correlation procedure. As the results of cross-correlation indicated that in most cases the relationship between government expenditure and private investment was very week in third lag, Granger causality test was not performed in this lag except the case of Estonia.

Granger causality tests have shown that government expenditure does not Granger cause private investment in the case of Bulgaria, Latvia, Lithuania and Slovenia. In the cases of these countries, it was not established that private investment Granger causes government expenditure. As Granger causality was not established between analyzed indicators, the results of these tests are not presented in this paper.

In the case of Estonia, it was established that cyclical component of private investment Granger causes cyclical component of government expenditure after one year (see Table IV). The same result was obtained using variables expressed as annual changes.

According to the results of cross-correlations, impact of private investment's increase on government expenditure is positive in the case of Estonia. In the second lag there is negative relationship between private investment and government expenditure, and the impact of factors is bidirectional according to Granger causality tests. Granger causality test has confirmed the negative impact of government expenditure's increase before three years on private investment in the case of variables expressed as annual change, but not the cyclical component.

\section{CONCLUSION}

The following conclusions can be formulated summarizing the research results of relationship between government expenditure and private investment in small open economies: 1) Governments of small open economies confront with large limitations pursuing fiscal policy. Fiscal policy instruments are less effective in small open economies than in large and less open ones. Small open economies tend to have higher growth volatility and are more vulnerable to external economic shocks, but governments of small open economies have very small abilities to smooth out this volatility.

2) It was established only very week relationship between government expenditure and private investment, but according to overall research results there is evidence that government expenditure crowds out private investment in Estonia, Latvia Lithuania and Slovenia.

3) The further research of relationship between private investment and different types of government expenditure should be taken in order to get more precise results. Also there should be more attention paid to the factors determining government expenditure impact on private investment.

\section{REFERENCES}

[1] S. R. Larson, "The economic case for limited government," Prosperitas: A Policy Analysis from the Center for Freedom and Prosperity Foundation, vol. 7, no. 3, pp. 1-12, 2007.
[2] D. Giannaros, B. Kolluri, and M. Panik, "An empirical analysis of the effects of government spending on capital investment: evidence from O.E.C.D. countries," International Economic Journal, vol. 13, no. 1, pp. 45-55, 1999.

[3] D. Furceri and R. M. Sousa, "The impact of government spending on the private sector: crowding-out versus crowding-in effects," Kyklos, vol. 64 , no. 4, pp. 516-533, 2011.

[4] D. Furceri and R. M. Sousa, "Does government spending crowd out private consumption and investment?" World Economics, vol. 12, no. 4, pp. 153-169, 2011.

[5] G. R. Motlaleng, P. Nangula, and B. Moffat, "Effectiveness of fiscal spending in the presence of persistant budget deficitit in Namibia: crowding out or crowding in," International Journal of Economics and Research, vol. 2, no. 1, pp. 96-117, 2011.

[6] S. Shaheen, R. Kousar, and T. A. Nav, "Impact of trade Liberalization on the government consumption expenditures of Pakistan," J. Asian Dev. Stud, vol. 1, issue 2, pp. 45-50, June 2012.

[7] A. Maravalle and P. Claeys, "Boom-bust cycles and procyclical fiscal policy in a small open economy," Journal of Policy Modeling, vol. 34, no. 5, pp. 735-754, 2012

[8] C. D. Roldán, C. M. Cuerva, and J. J. R. Guerrero, "On the relationship between the government balance and the current account," presented at the XIV Conference on International Economics, Palma de Mallorca, June 27-28, 2013.

[9] I. Down, "Trade openness, country size and economic volatility: the compensation hypothesis revisited," Business and Politics, De Gruyter, vol. 9, no. 2, pp. 1-22, Sept. 2007.

[10] G. Karras, "Trade openness and the effectiveness of fiscal policy: some empirical evidence," International Review of Economics, vol. 59, issue 3, pp. 303-313, 2012.

[11] G. Corsetti, A. Meier, and G. J. Müller. (January 2007). International dimensions of fiscal policy transmission. [Online]. Available: http://www.economicdynamics.org/meetpapers/2007/paper_726.pdf

[12] E. Ilzetzki, E. G. Mendoza, and C. A. Vegh, "How big (small) are fiscal multipliers?" NBER Working Paper No. 16479, Oct. 2010.

[13] M. Kandil, "Public spending and the macroeconomy: evidence from developing and developed countries," International Journal of Business and Economics, vol. 8, no. 2, pp. 133-158, 2009.

[14] H. S. Atesoglu and J. Emerson, "Fiscal policy, profits and investment: some additional evidence," Applied Economics Letters, vol. 15, no.13, pp. 1047-1051, 2008.

[15] Y. Kustepli, "Effectiveness of fiscal spending? Crowding out and/or crowding in?" Yönetim ve Ekonomi, vol. 12, no. 1, pp. 185-192, 2005.

[16] H. Kim. (March 12, 2004). Hodrick-Prescott Filter. [Online]. Available: http://www.auburn.edu/ hzk0001/hpfilter.pdf

[17] M. O. Ravn and H. Uhlig, "Notes on adjusting the hodrick-prescott filter for the frequency of observations," The Review of Economics and Statistics, vol. 84, no. 2, pp. 371-380, 2002.

[18] I. Szarowska, "Development and the cyclicality of government spending in the Czech Republic," MPRA Paper No. 32353, 2011.

[19] European Commission, EUROSTAT Database, 2013.

[20] European Commission, Annual Macroeconomic Database of the European Commission (AMECO), 2013.

[21] World Bank, World Development Indicators, Database, 2013.

[22] SPSS Trends ${ }^{\text {TM }}$ 10.0. SPSS Inc. United States of America. (1999) [Online]. Available: http://www.bf.lu.lv/grozs/Datorlietas/SPSS/SPSS\%20Trends\%2010.0 .pdf

[23] L. Sinevičienè, “The Impact of Government's Fiscal Policy on Private Investment," Ph.D. dissertation, Kaunas University of Technology, Lithuania, 2013.

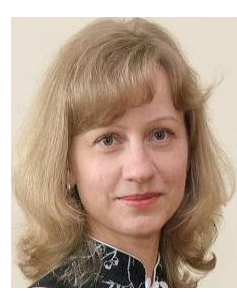

Lina Sinevičienė was born in Lithuania on 3rd of June, in 1977. She obtained a doctor degree in social sciences (economics) at Kaunas University of Technology in 2013. She is a lecturer at Department of Finance, Faculty of Economics and Management, Kaunas University of Technology, Lithuania Address: K. Donelaičio str. 73, LT-44309 Kaunas, Lithuania. She has Chief Financial Officer working experience in private enterprises. Research interests: Capital Investment, Fiscal Policy, Fiscal Policy Interaction with Private Investment, Public Finance. 